\title{
Pengaruh Penusukan Tunggal Titik Akupunktur Telinga Ciao Kan terhadap Tekanan Darah Dan Frekuensi Denyut Jantung
}

\author{
Yanti Ivana Suryanto \\ Bagian Fisiologi Universitas Kristen Duta Wacana \\ Gedung Agape lantai 5, Jl. Dr. Wahidin 5-25 Yogyakarta, Indonesia 55224; e-mail: yanti_iv@yahoo.com
}

\begin{abstract}
ABSTRAK
Dalam praktek klinis kedokteran gigi, seringkali pasien datang dengan tekanan darah yang tinggi meskipun ia tidak memiliki riwayat hipertensi sebelumnya. Pada kondisi ini, tingginya tekanan darah seringkali dipengaruhi oleh tingkat kecemasan pasien yang nantinya akan mempengaruhi sistem saraf otonom. Akupunktur merupakan suatu metode pengobatan dengan penusukan jarum tanpa memasukkan bahan kimia ke dalam tubuh pasien. Penelitian ini bertujuan untuk mengkaji pengaruh penusukan tunggal titik akupunktur telinga Ciao Kan terhadap tekanan darah dan frekuensi denyut jantung. Hipotesis yang diajukan adalah penusukan tunggal titik akupunktur telinga Ciao Kan menyebabkan terjadinya penurunan tekanan darah dan frekuensi denyut jantung. Penelitian ini merupakan penelitian eksperimental dengan mempergunakan rancangan penelitian pre-post test design. Subjek penelitian adalah laki-laki berusia 25-35 tahun dengan tekanan sistolik lebih atau sama dengan $130 \mathrm{mmHg}$ yang memenuhi kriteria inklusi dan eksklusi. Subjek menjalani orthostatic stress test, penusukan titik akupunktur telinga Ciao Kan, pengukuran tekanan darah dan frekuensi denyut jantung. Metode statistik yang dipergunakan adalah uji t, uji korelasi Pearson, dan uji ANOVA satu jalur. Uji $\mathrm{t}$ dilakukan pada data yang telah ditransformasi. Tekanan sistolik turun signifikan pada subyek penelitian selama perlakuan $(p<0,05)$ namun kemudian naik kembali. Frekuensi denyut jantung juga mengalami penurunan signifikan $(p<0,05)$ selama perlakuan dan naik kembali. Uji korelasi Pearson dilakukan untuk melihat korelasi antara tekanan arteri rata-rata dengan frekuensi denyut jantung. Hasil uji korelasi menunjukkan adanya korelasi positif antara tekanan arteri rata-rata dan frekuensi denyut jantung $(r=0,373)$. Uji ANOVA satu jalur menunjukkan tidak adanya perbedaan nilai tekanan sistolik, tekanan diastolik, tekanan arteri rata-rata, dan frekuensi denyut jantung antar kelompok dengan respon terhadap orthostatic stress test normal, hipertonus, maupun hipotonus $(p>0,05)$. Dengan demikian dapat dikatakan bahwa penusukan tunggal titik akupunktur telinga Ciao Kan menyebabkan terjadinya penurunan tekanan darah dan frekuensi denyut jantung.
\end{abstract}

Maj Ked Gi. Desember 2014; 21(2): 141 - 148

Kata kunci: Ciao Kan, tekanan sistolik, frekuensi denyut jantung

ABSTRACT: The Effect of Single Acupuncture on Ciao Kan Ear Acupoint on Blood Pressure and Heart Rate In dental clinical practice. Patient sometime come with high blood pressure even though they have no history of hypertension. In this condition, high blood pressure could be influenced by anxiety that will have an effect on autonomic nerve system. Acupuncture is a healing method with needle puncture without giving chemical substance to patient's body. This research aimed at evaluating the effect of a single acupuncture on Ciao Kan ear acupoint on blood pressure and heart rate. Hypothesis of this research was single acupuncture on Ciao Kan ear acupoint could decrease blood pressure and heart rate. This was a pre-post test design experiment. Subjects were men, $25-35$ years old with systolic blood pressure equal or more than $130 \mathrm{mmHg}$ who met the inclusion and exclusion criteria. Subject did orthostatic stress test, acupuncture on Ciao Kan ear acupoint, blood pressure measurement, and heart rate measurement.T test was done on the transformed data. Systolic blood pressure decreased significantly $(p<0.05)$ during acupuncture and then increased afterward. Heart rates also decreased significantly $(p<0.05)$ during acupuncture and then increased afterward. Pearson correlation test was done to see the correlation between mean arterial pressure and heart rate. The results showed a positive correlation between mean arterial pressure and heart rate $(r=0.373)$. One way ANOVA showed no systolic, diastolic, mean arterial pressure, and heart rate differences between groups in response to orthostatic stress test normal, hyper tone, or hypo tone $(p>0.05)$. It could be said that single acupuncture on Ciao Kan ear acupoint could decrease blood pressure and heart rate.

Maj Ked Gi. Desember 2014; 21(2): 141 - 148

Keywords: Ciao Kan-systolic blood pressure-heart rate 


\section{PENDAHULUAN}

Tekanan darah merupakan salah satu parameter fungsi sistem kardiovaskular pada manusia. Dalam praktek klinis kedokteran gigi, seringkali pasien datang dengan tekanan darah yang tinggi meskipun ia tidak memiliki riwayat hipertensi sebelumnya. Pada kondisi ini, tingginya tekanan darah seringkali dipengaruhi oleh tingkat kecemasan pasien yang nantinya akan mempengaruhi sistem saraf otonom. Meskipun belum ada penelitian klinisnya, direkomendasikan untuk tidak melakukan prosedur non gawat darurat pada pasien dengan tekanan darah lebih dari 180/110 $\mathrm{mmHg} .{ }^{1}$ Usaha untuk menurunkan tekanan darah dalam waktu yang singkat dibutuhkan agar dokter gigi dapat melakukan berbagai prosedur yang diperlukan pasien secara optimal dan aman. Beberapa hal seperti curah jantung dan resistensi perifer mempengaruhi tekanan darah seseorang, dimana curah jantung dipengaruhi oleh volume sekuncup dan frekuensi denyut jantung. Tindakan yang menurunkan volume sekuncup maupun frekuensi denyut jantung akan dapat menurunkan tekanan darah seseorang.

Akupunktur merupakan cara pengobatan dengan penusukan pada titik-titik tertentu di dalam tubuh. Beberapa penelitian mencoba menjelaskan peranan akupuntur dalam menurunkan tekanan darah. ${ }^{2,3,4}$ Akupunktur bekerja pada tubuh diduga dengan cara melepaskan neurotransmiter yang terlibat pada berbagai proses dalam tubuh. Menurut teori neurohumoral efek akupunktur dimediasi melalui sistem saraf. ${ }^{5,6}$ Titik akupunktur telinga Ciao Kan terletak pada pertemuan krus inferius antiheliks dan heliks. Bagian ini dipersarafi oleh cabang mandibularis nervus trigeminus maupun cabang aurikularis nervus vagus sehingga manipulasi pada titik ini akan menstimulasi nervus trigeminus dan vagus. ${ }^{7}$ Nervus trigeminus merupakan serabut aferen kuat yang menimbulkan reaksi parasimpatomimetik, begitu pula dengan nervus vagus.

Pacuan oleh saraf simpatis mampu meningkatkan tekanan darah dan frekuensi denyut jantung sedangkan pacuan oleh saraf parasimpatis mampu menurunkan tekanan darah dan frekuensi denyut jantung. 8,9 Gambaran obyektif mengenai aktivitas saraf otonom seseorang terhadap tekanan darah dapat ditunjukkan dengan tes ortostatik, misalnya schellong test. ${ }^{10,11}$ Penelitian terhadap 16 pasang titik akupunktur telinga yang dilakukan oleh Gaponjuk dan Sherkovina ${ }^{12}$ menemukan bahwa penusukan pada titik tersebut mengakibatkan terjadinya penurunan tekanan darah melalui mekanisme penurunan volume semenit jantung.

Berdasarkan beberapa hal tersebut, peneliti ingin mengetahui efek penusukan tunggal titik akupunktur telinga simpatis terhadap tekanan darah dan frekuensi denyut jantung.

\section{METODE PENELITIAN}

Penelitian ini termasuk penelitian eksperimental dengan mempergunakan rancangan penelitian pre-post test design. Subjek berjumlah 28 orang dengan kriteria inklusi laki-laki berusia 25 sampai dengan 35 tahun; memiliki tekanan sistolik lebih atau sama dengan $130 \mathrm{mmHg}$; tidak sedang mengkonsumsi obat apapun sampai dengan 3 hari sebelum penelitian; dan bersedia menjalani semua prosedur penelitian. Kriteria eksklusi adalah hasil rekaman elektrokardiogram menunjukkan adanya abnormalitas jantung; menderita diabetes melitus dan atau asma bronkhiale; memiliki daun telinga dengan anatomi double helix; selama proses penelitian hasil pengukuran tekanan darah menunjukkan adanya penurunan lebih dari $20 \%$ dan atau frekuensi denyut jantung turun menjadi kurang dari 60 kali per menit. Penelitian dilakukan di RSU Bethesda Lempuyangwangi, Yogyakarta. Rancangan penelitian ini telah disetujui oleh Komisi Etik Penelitian Kedokteran dan Kesehatan Fakultas Kedokteran Universitas Gadjah Mada (Nomor: KE/ FK/485/EC).

Perbedaan nilai tekanan darah dan frekuensi denyut jantung sebelum dan setelah perlakuan maupun antar kelompok waktu selama perlakuan diuji dengan uji t. Uji Anova satu jalur dilakukan untuk menguji kemaknaan perbedaan antar kelompok dengan respon orthostatic stress test yang berbeda-beda. Uji korelasi antara nilai tekanan darah dan frekuensi denyut jantung dilakukan dengan uji korelasi Pearson. 
Tabel 1. Karakteristik awal penelitian

\begin{tabular}{lcc}
\hline Karakteristik & Rerata \pm SE \\
\hline Jumlah & 28 & \\
Usia & $25-35$ tahun & $29,14 \pm 0,65$ \\
Tekanan Sistolik & $131-152 \mathrm{mmHg}$ & $140,07 \pm 0,85$ \\
Tekanan Diastolik & $76-99 \mathrm{mmHg}$ & $88,60 \pm 1,27$ \\
Frekuensi Denyut Jantung & $57-93 \times /$ menit & $75.21 \pm 1,70$ \\
Orthostatic stress test & & \\
$\quad$ Normal & 9 orang $(32,15 \%)$ & \\
$\quad$ Hipertonus & 9 orang $(32,15 \%)$ & \\
$\quad$ Hipotonus & 10 orang $(35,7 \%)$ & \\
\hline
\end{tabular}

Subjek dipilih berdasarkan kriteria inklusi dan eksklusi. Penjelasan dan persetujuan tindakan medis didapatkan sebelum pemberian tindakan. Pelaksanaan tindakan: Subjek berbaring dengan tenang pada tempat tidur selama 5 menit, tekanan darah dan frekuensi denyut jantung pada posisi berbaring diukur setiap menit selama 5 menit. Subjek kemudian diminta berdiri selama 5 menit, tekanan darah dan frekuensi denyut jantung pada posisi berdiri diukur setiap menit selama 5 menit. Perbedaan tekanan darah dan frekuensi denyut jantung pada posisi berbaring dan berdiri dianalisis kemudian subjek dikelompokkan menjadi tiga kelompok berdasarkan respon orthostatic stress test (normal, hipertonus, dan hipotonus). ${ }^{10}$ Hasil orthostatic stress test dikatakan normal apabila terjadi perubahan tekanan sistolik kurang dari 8 $\mathrm{mmHg}$ dan frekuensi denyut jantung bertambah kurang dari 22 kali per menit; hipertonus apabila tekanan sistolik bertambah lebih dari $8 \mathrm{mmHg}$ dan frekuensi denyut jantung bertambah lebih dari 22 kali permenit; dan hipotonus apabila tekanan sistolik berkurang lebih dari $8 \mathrm{mmHg}$ dan frekuensi denyut jantung bertambah.

Subjek diminta berbaring kembali dengan tenang pada tempat tidur, tekanan darah dan frekuensi denyut jantung diukur. Kedua telinga selanjutnya dibersihkan dengan alkohol $70 \%$, jarum akupunktur telinga dipasang dengan mempergunakan pinset. Jarum ditinggalkan tanpa manipulasi selama 20 menit. Setelah selesai jarum diambil dengan mempergunakan pinset dan telinga dibersihkan kembali dengan alkohol
$70 \%$. Pengukuran tekanan darah dan denyut nadi dilakukan tepat sebelum penusukan titik akupunktur Ciao Kan, setiap 5 menit setelah penusukan titik akupunktur Ciao Kan (dalam posisi jarum terpasang), dan 5 menit setelah jarum dilepas. Apabila dalam pelaksanaan tindakan didapatkan penurunan tekanan darah $>20 \%$ dan atau frekuensi denyut jantung menjadi $<60 \mathrm{kali} / \mathrm{menit}$ atau subjek pingsan pada orthostatic stress test, penelitian dihentikan.

\section{HASIL PENELITIAN}

Ringkasan karakteristik awal penelitian dijabarkan pada Tabel 1. Tekanan sistolik, tekanan tekanan diastolik, dan frekuensi denyut jantung menunjukkan adanya perubahan selama perlakuan. Ketika hasil perlakuan dikelompokkan menurut hasil orthostatic stress test, terlihat adanya pola perbedaan perubahan tekanan darah dan frekuensi denyut jantung antar kelompok. Hasil perlakuan setelah dikelompokkan menurut hasil orthostatic stress test ditampilkan pada Tabel 2.

Kelompok dengan respon terhadap orthostatic stress test normal (kelompok normal) menunjukkan adanya penurunan tekanan sistolik, tekanan diastolik, tekanan arteri rata-rata, dan frekuensi denyut jantung pada akhir penelitian dibandingkan awal penelitian. Tekanan sistolik terendah dicapai pada menit ke-20 namun tidak berbeda signifikan dibandingkan awal penelitian $(p>0,05)$. Tekanan diastolik terendah dicapai pada menit ke-20 yang berbeda signifikan dibandingkan awal penelitian 
Tabel 2. Ringkasan perubahan tekanan sistolik, diastolik, dan frekuensi denyut jantung selama perlakuan pada kelompok dengan respon terhadap orthostatic stress test normal, hipertonus, dan hipotonus

\begin{tabular}{lccc}
\hline & Normal & Hipertonus & Hipotonus \\
\hline & Rerata \pm SE & Rerata \pm SE & Rerata \pm SE \\
\hline T Sistolik awal & $139,44 \pm, 78$ & $138,33 \pm 1,80$ & $142,20 \pm 1,47$ \\
T Sistolik menit 5 & $139,44 \pm 1,56$ & $136,89 \pm 1,87$ & $137,70 \pm 2,40$ \\
T Sistolik menit 10 & $138,11 \pm 1,74$ & $136,11 \pm 1,64$ & $137,10 \pm 2,05$ \\
T Sistolik menit 15 & $138,67 \pm 2,01$ & $135,89 \pm 2,33$ & $138,30 \pm 2,86$ \\
T Sistolik menit 20 & $137,00 \pm 1,72$ & $136,33 \pm 2,19$ & $137 \pm 1,84$ \\
T Sistolik akhir & $137,33 \pm 1,55$ & $136,33 \pm 2,51$ & $138,80 \pm 1,85$ \\
T Diastolik awal & $91,67 \pm 1,77$ & $86,67 \pm 2,28$ & $87,60 \pm 2,33$ \\
T Diastolik menit 5 & $90,67 \pm 1,80$ & $85,56 \pm 2,27$ & $87,40 \pm 2,56$ \\
T Diastolik menit 10 & $89,33 \pm 2,32$ & $85,56 \pm 2,80$ & $85,20 \pm 2,15$ \\
T Diastolik menit 15 & $89,00 \pm 2,07$ & $84,33 \pm 2,63$ & $84,20 \pm 3,14$ \\
T Diastolik menit 20 & $88,56 \pm 1,80$ & $84,67 \pm 3,00$ & $84,20 \pm 1,99$ \\
T Diastolik akhir & $90,33 \pm 1,83$ & $85,00 \pm 3,00$ & $85,60 \pm 2,37$ \\
FDJ awal & $76,00 \pm 3,10$ & $79,22 \pm 2,25$ & $70,90 \pm 2,96$ \\
FDJ menit 5 & $75,22 \pm 2,64$ & $77,56 \pm 2,14$ & $68,90 \pm 2,59$ \\
FDJ menit 10 & $73,44 \pm 2,70$ & $78,11 \pm 2,14$ & $68,80 \pm 3,88$ \\
FDJ menit 15 & $75,00 \pm 2,60$ & $79,00 \pm 1,94$ & $66,50 \pm 2,95$ \\
FDJ menit 20 & $75,44 \pm 2,81$ & $78,78 \pm 1,81$ & $68,50 \pm 3,91$ \\
FDJ akhir & $74,44 \pm 2,75$ & $81,56 \pm 1,94$ & $71,90 \pm 3,79$ \\
\hline
\end{tabular}

SE: Standard Error, T: Tekanan darah (mmHg), FDJ: Frekuensi denyut jantung (kali/menit),

$(p<0,05)$. Tekanan arteri rata-rata terendah dicapai pada menit-20 yang berbeda signifikan dibandingkan awal penelitian $(p<0,05)$. Frekuensi denyut jantung terendah dicapai pada menit-10 yang berbeda signifikan pula dibandingkan awal penelitian $(p<0,05)$.

Kelompok dengan respon terhadap orthostatic stress test hipertonus (kelompok hipertonus) menunjukkan adanya penurunan tekanan sistolik, tekanan diastolik, dan tekanan arteri rata-rata pada akhir penelitian dibandingkan awal penelitian serta penurunan frekuensi denyut jantung sampai menit ke-20 yang diikuti dengan peningkatan melebihi nilai awal pada akhir penelitian. Tekanan sistolik pada menit ke- 5 turun dibandingkan awal penelitian yang berbeda signifikan dibandingkan awal penelitian $(p<0,05)$. Tekanan diastolik terendah dicapai pada menit ke-15 yang berbeda signifikan dibandingkan awal penelitian $(p<0,05)$. Tekanan arteri rata-rata terendah dicapai pada menit ke-15 yang berbeda signifikan dibandingkan awal penelitian $(p<0,05)$. Frekuensi denyut jantung terendah dicapai pada menit-5 yang berbeda signifikan pula dibandingkan awal penelitian $(p<0,05)$.

Kelompok dengan respon terhadap orthostatic stress test hipotonus (kelompok hipotonus) menunjukkan adanya penurunan tekanan sistolik, tekanan diastolik, dan tekanan arteri rata-rata pada akhir penelitian dibandingkan awal penelitian, serta penurunan frekuensi denyut jantung sampai menit ke-20 yang diikuti dengan peningkatan melebihi nilai awal pada akhir penelitian. Tekanan sistolik terendah dicapai pada menit ke-20 yang berbeda signifikan dibandingkan awal penelitian 
$(p<0,05)$. Tekanan diastolik terendah dicapai pada menit ke-20 yang berbeda signifikan dibandingkan awal penelitian $(p<0,05)$. Tekanan arteri rata-rata terendah dicapai pada menit ke-20 yang berbeda signifikan dibandingkan awal penelitian $(p<0,05)$. Frekuensi denyut jantung terendah dicapai pada menit-15 yang berbeda signifikan pula dibandingkan awal penelitian $(p<0,05)$.

Uji korelasi Pearson dilakukan untuk melihat korelasi antara tekanan arteri rata-rata dengan frekuensi denyut jantung. Hasil uji korelasi menunjukkan adanya korelasi positif antara tekanan arteri rata-rata dan frekuensi denyut jantung $(r$ $=0,373)$. Uji Anova satu jalur menunjukkan tidak adanya perbedaan nilai tekanan sistolik, tekanan diastolik, tekanan arteri rata-rata, dan frekuensi denyut jantung antar kelompok dengan respon terhadap orthostatic stress test normal, hipertonus, maupun hipotonus $(p>0,05)$.

\section{PEMBAHASAN}

Penelitian ini melibatkan subjek berjenis kelamin laki-laki untuk meminimalkan efek dari perbedaan hormon seksual, anatomi serta komposisi tubuh yang dapat mempengaruhi tekanan darah. Androgen pada laki-laki berkontribusi pada vasokonstriksi, atherosklerosis, dan stimulasi sistem renin-angiotensin-aldosteron yang dapat meningkatkan tekanan darah. ${ }^{13}$ Aktivitas simpatis pada laki-laki lebih tinggi sedangkan aktivitas parasimpatis pada perempuan lebih tinggi. ${ }^{14}$

Terdapat tiga kelompok respon terhadap orthostatic stress test pada penelitian ini, yaitu kelompok normal, hipertonus, dan hipotonus. Ketiga kelompok tersebut menunjukkan perubahan tekanan darah dan frekuensi denyut jantung dengan periode waktu yang berbeda setelah dilakukan penusukan titik akupunktur telinga Ciao Kan. Pada kelompok dengan respon orthostatic stress test hipertonus (hipertonus), frekuensi denyut jantung turun mencapai titik terendah pada menit ke-5, pada kelompok dengan respon orthostatic stress test hipotonus (hipotonus) pada menit ke-15, dan pada kelompok dengan respon orthostatic stress test normal (normal) pada menit ke-10.
Adanya penurunan frekuensi denyut jantung segera setelah dimulainya perlakuan, ditunjukkan dengan menurunnya frekuensi denyut jantung mulai dari menit ke- 5 perlakuan pada ketiga kelompok diduga terjadi karena adanya peningkatan aktivitas saraf parasimpatis pada penusukan titik akupunktur telinga Ciao Kan. Kelompok hipertonus menunjukkan respon yang paling cepat terhadap penurunan ini karena saraf simpatis hiperreaktif. Kelompok hipotonus yang memiliki respon simpatis yang lebih lambat menunjukkan penurunan frekuensi denyut jantung terendah. Kelompok normal menunjukkan respon simpatis di antara kelompok hipertonus dan hipotonus.

Seperti halnya frekuensi denyut jantung, tekanan sistolik terendah pun dijumpai pada waktu yang berlainan antar kelompok dengan respon orthostatic stress test yang berbeda. Kelompok hipertonus mengalami penurunan tekanan sistolik terendah pada menit ke-15 perlakuan yang kemudian naik kembali sehingga perbedaannya tidak signifikan dengan awal perlakuan. Kelompok hipotonus mengalami perurunan tekanan sistolik terendah pada menit ke-20 perlakuan yang kemudian naik kembali sehingga di akhir penelitian tidak dijumpai perbedaan yang signifikan dengan awal perlakuan.

Kelompok normal menunjukkan adanya penurunan tekanan sistolik terendah pada menit ke-20 yang kemudian naik kembali meskipun tidak signifikan secara statistik. Seperti pada frekuensi denyut jantung yaitu respon kelompok normal berada di antara kelompok hipertonus dan hipotonus, tekanan darah terendah dari kelompok normal seharusnya berada pada menit antara menit ke-15 dan 20. Respon fisiologis pada subjek dalam kelompok normal yang membutuhkan waktu sekitar 3 sampai 5 menit berusaha mengembalikan tekanan sistolik ke nilai awal setelah terjadi perubahan sehingga tekanan darah sudah naik kembali ketika dilakukan pengukuran pada menit ke-20 sehingga hasilnya tidak signifikan secara statistik.

Akupunktur ditunjukkan memiliki efek yang terkait erat dengan refleks somato-otonom. ${ }^{15,16,17}$ Peran sistem saraf otonom pada penelitian ini 
ditunjukkan dengan adanya penurunan frekuensi denyut jantung yang signifikan. Peran yang kemungkinan terjadi berupa peningkatan aktivitas saraf parasimpatis dan penurunan saraf simpatis. Guo dkk ${ }^{18}$ menunjukkan bahwa akupunktur bekerja dengan mempengaruhi aliran parasimpatis dan fungsi kardiovaskular melalui mekanisme enkefalinergik.

Perubahan pada tekanan darah rata-rata akan mengaktifkan refleks baroreseptor yang diperantarai saraf otonom sehingga jantung dan pembuluh darah akan terpacu untuk menyesuaikan curah jantung dan resistensi perifer total sebagai usaha untuk memulihkan tekanan darah ke titik sebelum terjadi penurunan. Reseptor terpenting yang berperan pada pengaturan terus-menerus tekanan darah adalah baroreseptor yang terletak pada sinus karotikus dan lengkung aorta. ${ }^{8,9} \mathrm{Apabila}$ terdapat rangsang berupa penurunan tekanan darah pusat kardiovaskuler akan terpicu untuk meningkatkan aktivitas jantung dan menurunkan keluaran parasimpatis. ${ }^{8,9}$ Pola aktivitas eferen ini menyebabkan peningkatan frekuensi denyut jantung dan volume sekuncup disertai vasokonstriksi arteriola. Perubahan-perubahan ini menyebabkan terjadinya peningkatan curah jantung dan resistensi perifer total, sehingga tekanan darah naik kembali. ${ }^{9}$

Analisis korelasi Pearson yang menyatakan adanya korelasi positif antara tekanan arteri ratarata dan frekuensi denyut jantung menunjukkan bahwa perubahan tekanan darah dipengaruhi oleh perubahan frekuensi denyut jantung. Penurunan frekuensi denyut jantung akan menyebabkan terjadinya penurunan tekanan darah.

Ketika dilakukan uji beda terhadap tekanan darah dan frekuensi denyut jantung antar kelompok dengan respon orthostatic stress test yang berbeda dengan uji Anova satu jalur tidak didapatkan perbedaan yang bermakna secara statistik. Hal ini menimbulkan dugaan bahwa saraf otonom bukan satu-satunya yang berpengaruh pada perubahan tekanan darah akibat akupunktur.

Pada penelitian ini, terjadi penurunan tekanan darah meskipun terjadi penurunan aktivitas saraf parasimpatis. Tekanan darah yang tidak segera berubah mengikuti penurunan saraf parasimpatis memperkuat dugaan bahwa mekanisme kerja akupunktur tidak hanya disebabkan oleh perubahan para sistem saraf. Hal ini sesuai dengan pendapat Winfree $^{19}$ bahwa teori neurohumoral tidak dapat menerangkan semua peristiwa yang terjadi pada penusukan titik akupunktur.

Terdapat beberapa hipotesis mengenai mekanisme kerja akupunktur. Friedeman ${ }^{3}$ menunjukkan bahwa akupunktur manual dapat menurunkan tekanan darah dengan lokasi modulasi berada ada supraspinal. Zhang $\mathrm{dkk}^{20}$ pada penelitiannya mengenai akupunktur yang dikombinasi dengan obat melaporkan bahwa terdapat penurunantekanandarah danneuropeptida $Y$ serum yang lebih besar dibandingkan dengan kontrol. Neuropeptida Y terdapat di berbagai tempat di otak dan sistem saraf otonom. Polipeptida ini memperkuat efek vasokonstriksi norepinefrin. Penurunan neuropeptida $Y$ dikaitkan dengan penurunan efek vasokonstriktor norepinefrin sehingga pada akhirnya akan didapatkan penurunan tekanan darah. ${ }^{8}$ Marcus $^{21}$ menyatakan bahwa efek akupunktur merupakan hasil dari beberapa faktor yang terjadi selama penetrasi kulit awal: 1) terjadi kerusakan jaringan yang disebabkan oleh penetrasi kulit sehingga menyebabkan terjadinya pelepasan mediator inflamasi yang mensensitisasi ujung saraf lokal; 2) efek akupunktur merupakan hasil langsung dari kerusakan jaringan yang proporsional dengan kedalaman penjaruman dan diameter jarum, kerusakan ini mengatur dosis mediator inflamasi yang dilepaskan; 3) jarum mungkin juga menyebabkan stimulasi saraf dan otot secara langsung. Vasodilatasi menyeluruh mungkin terjadi akibat dari adanya Calcitonin gene-related peptide yang diduga dilepaskan pada penusukan titik akupunktur secara langsung maupun tidak langsung. ${ }^{22}$ Vasodilatasi perifer akan menurunkan tahanan perifer, mengurangi aliran balik vena ke jantung, mengurangi volume semenit jantung, dan akhirnya menurunkan tekanan darah.

Titik akupunktur telinga Ciao Kan berefek sedasi dan menekan rasa nyeri sehingga umum dipilih oleh para akupunkturis untuk mengurangi rasa nyeri. ${ }^{12}$ Aplikasi akupunktur pada titik ini 
juga akan menstimulasi cabang aurikular nervus vagus yang membawa serabut saraf parasimpatis ke jantung sehingga terjadi peningkatan aktivitas saraf parasimpatis setelah dilakukan penusukan titik akupunktur telinga Ciao Kan satu kali, yang menyebabkan berkurangnya frekuensi denyut jantung yang pada akhirnya dapat menurunkan tekanan darah.

Hasil dari penelitian ini sejalan dengan penelitian yang dilakukan oleh Gaponjuk dan Sherkovina $^{12}$ bahwa tekanan sistolik maupun diastolik turun setelah stimulasi. Hal ini semakin memperkuat pendapat bahwa penusukan titik akupunktur telinga Ciao Kan sebanyak satu kali mampu menurunkan tekanan darah. Penelitian ini memiliki keterbatasan yaitu bahwa penelitian ini merupakan penelitian sesaat yang tidak dapat langsung dianalogikan dengan efek terapetik akupunktur terhadap kondisi hipertensi.

\section{KESIMPULAN}

Penusukan titik akupunktur telinga Ciao Kan menyebabkan terjadinya penurunan tekanan darah dan frekuensi denyut jantung. Dilakukan penelitian selama satu seri terapi atau dengan terapi kombinasi untuk mengetahui efek terapetik dari penusukan titik akupunktur telinga Ciao Kan. Saran dilakukan penelitian lebih lanjut untuk mengukur parameter-parameter kimiawi dalam darah (misalnya calcitonin gene related peptidel CGRP) yang mungkin terlibat pada mekanisme efek penurunan tekanan darah pada penusukan titik akupunktur telinga Ciao Kan. Penelitian lebih lanjut disarankan efek penekanan titik akupunktur telinga Ciao Kan terhadap tekanan darah maupun frekuensi denyut jantung dikarenakan efek yang ditimbulkan oleh akupresur diharapkan mirip dengan efek akupunktur.

\section{DAFTAR PUSTAKA}

1. Hogan J, Radhakrishnan J. The Assessment and Importance of Hypertension in the Dental Setting. Dent Clin N Am. 2012; 56: 731-45.

2. Wang J, Xiong X, Liu W. Acupuncture for essential hypertension. In J Cardiol. 2013; 169: 317-26
3. Friedemann T, Li W, Wang Z. Inhibitory regulation of blood pressure by manual acupuncture in the anesthetized rat. Auton Neurosci-Basic. 2009;151: 178-82

4. Li P, Longhurst JC. Neural Mechanism of electroacupuncture's hypotensive effects. Auton Neurosci-Basic. 2010;157: 24-30.

5. Ulett GA. Beyond yin and yang: how acupuncture really works. St. Louis: Warren H, Green; 1992.

6. Mann F. A new system of acupuncture. In: Filshie J, White A. editors. Medical acupuncture. Edinburgh: Churchill Livingston; 1998.

7. Berkovitz BKB, Moxham BJ. Textbook of Head and neck anatomy. Barcelona: Wolfe; 1988.

8. Ganong WF. Review of medical physiology. $22^{\text {nd }}$ ed. San Fransisco: McGraw-Hill; 2005.

9. Sherwood L. Fisiologi manusia: dari sel ke sistem. Edisi 2. Jakarta: EGC; 2001.

10. Stewart JM, Medow MS, Alejos JC, Windle ML, Chin AJ, Herzberg G, Neish S. Orthostatic intolerance: an overview. 2006.diunduh: URL: http://www.e-medicine.com.

11. Van Ravenswaaij-Arts CMA, Kollee LAA, Hopman, JCW, Stoelinga GBA, Van Geijn HP. Heart rate variability. Heart.1993; 118: 43647.

12. Gaponjuk PJ, Sherkovina TJ. The clinical and physiological foundation of auricular acupuncture therapy in patient with hypertension disease. Acupunct Med. 1994; 12: 2-5.

13. Kienitz T, Quinkler M. Testosterone and blood pressure regulation. Kidney Blood Press Res. 2008; 31: 71-79.

14. Britton A, Shipley M, Malik M, Hnatkova K, Hemingway $\mathrm{H}$, Marmot $\mathrm{M}$. Changes in heart rate and heart rate variability over time in middle-aged men and women in the general population (from the Whitehall II Cohort Study). Am J Cardiol. 2007; 100: 534-37. 
15. Kline RL, Yeung $\mathrm{KY}$, Calaresu FR. Role of somatic nerves in the cardiovascular responses to stimulation of an acupuncture point in anesthetized rabbits. Exp Neurol. 1978; 61: 561-70.

16. Sato A, Sato $Y$, Suzuki A, Uchida S. Neural mechanism of the reflex inhibition and excitation of gastric motility elicited by acupuncture-like stimulation in anesthetized rats. Neurosci. Res. 1993; 18: 53-62.

17. Langevin HM, Churchill DL, Wu JR, Badger GJ, Yandow JA, Fox JR, Krag MH. Evidence of connective tissue involvement in acupuncture. FASEB J. 2002; 8: 872-74.

18. Guo Z, Li Min, Longhurst JC. Nucleus ambiguus cholinerguc neurons activated by acupuncture: Relation to enkephalin. Brain Research. 2012; 1442: 25-35.
19. Winfree AT. The Geometry of biological time. New York: Springer-Verlag; 1980.

20. Zhang $\mathrm{YL}$, Li CP, Peng M, Yang HS. Effect of acupuncture combined with medicine on neuropeptide $Y$ in the patient of hypertension. Zhongguo Zhen Jiu. 2005; 25:155-57.

21. Marcus P. Towards a dose of acupuncture. Acupunct Med; 1994; 12:78-82.

22. Shen YT, Pittman TJ, Buie PS, Bolduc DL, Kane SA, Koblan KS, Gould RJ, Lynch JJ Jr. Functional role of alpha-calcitonin gene-related peptide in the regulation of the cardiovascular system. J Pharmacol Exp Ther; 2001:551-58. 